\title{
IMPACT OF WATER-INDUCED PROCESSES ON THE DEVELOPMENT OF TARNS AND THEIR BASINS IN THE HIGH TATRAS
}

\author{
DÁVID TOMKO-KRÁLO, JURAJ HREŠKO, IMRICH JAKAB
}

Department of Ecology and Environmental Sciences, Faculty of Natural Sciences CPU in Nitra, Tr. A. Hlinku 1, 949 74 Nitra, Slovak Republic; e-mail: david.tomko.kralo@gmail.com; jhresko@ukf.sk; ijakab@ukf.sk

\begin{abstract}
Tomko-Králo D., Hreško J., Jakab I.: Impact of water-induced processes on development of the tarns and their basins in the High Tatras. Ekológia (Bratislava), Vol. 36, No. 3, p. 247-267, 2017.

In the report we concentrate on the influences of water-induced morphodynamic processes and surface flow on the development of tarns in alpine environment conditions of selected valleys in the High Tatras. Model areas are represented by higher basins parts in the Malá Studená valley and the Velká Studená valley, where we confirmed that slope-gravitational processes in the form of rockfall, water-gravitational processes in the form of debris flows, but also fluvial-proluvial processes as the accumulation of the soft fractions from the area of debris cones take part in the material deposition in the tarns. In this context we focused on the creation of the model of spatial distribution of the water-induced potential of material deposition in drainage tarn basins. The model includes three basic factors: slope and curvature of the relief and land cover character. Map processing with GIS technologies was done on the basis of a 3-D relief model, which allowed the locating of the local erosion bases areas, where the material could be accumulated. The achieved results confirmed the hypothesis that tarn basin development of the alpine environment is subordinated to permanent backfilling as a consequence of the cumulative influence of the several processes connected with rainfall and the runoff regime of the drainage basins.
\end{abstract}

Key words: debris flows, High Tatras, slope motions, tarns, Velká and Malá Studená valley, Slovak Republic.

\section{Introduction}

Tarns in alpine lakes -represent an autonomous phenomenon of the deglacial High Tatras landscape and are important evidence of the Pleistocene glacial activity in the conditions of the highest mountains of the Carpathians. Their evolution after the glacier recession especially influenced processes of the periglacial environment, as were the rock glaciers and consequently slope gravitational and water gravitational processes. Kotarba (1992) confirmed the most important activity of the debris flows in the Little Ice Age, but also in later periods at the beginning of the 19th century. Gregor and Pacl (2004) pointed out the processes of silting up in the High Tatras, which was confirmed by their photogrammetric measurements of the coastline changes. Increased trends of the debris flows activity in relation to the extreme 
rainfalls in the area of the High Tatras were confirmed by the research in the 1980s and also after the year 2000 (Kotarba, 2007; Kapusta et al., 2010). Permanent releasing of the fractions from the rock faces and their accumulation on the periphery of the kettles and glacial furrows formed more or less continual zones of the debris cones with more than a 25-degree slope. Rock faces and slopes with a high production of grains that fall to the peripheries of the tarns create convex promontories running into the water area and are gradually seated by the vegetation. Debris flows served by clastic particles from the gully resource areas normally predisposed by mylonite zones evidently contributed to the filling of the lake basins.

\section{Objective}

The goal of our work is to create a model of potential deposition of material by running water and thus contribute to the knowledge about the inclination of the tarn basins to silting up of the tarns. The result is a map of potential material deposition, which generates the base for next verification in conditions of the tarn basins research in the Malá Studená dolina valley and Velká Studená dolina valley in the High Tatras. The base step for this research was the terrain research with the photodocumentation, its archiving, interpretation and analysis of the terrain research. Subsequently, we created a digital model of the potential deposition by water-induced processes in GIS scene.

\section{Study area and natural conditions}

The research area represents higher parts of the Vel'ká Studená dolina valley and Malá Studená dolina valley drainage basin, in the central part of the High Tatras, which are the highest mountains of the Carpathians mountain range. The major part of the High Tatras extends over the territory of Slovakia and in a small scale they extend to Poland. The High Tatras Mountains have had the status of national park since 1945, when the National Nature Reserve - Studené doliny valleys was declared, which means that this area has the highest level of nature protection in Slovakia. The natural reservation protects all forms of glacial relief, including the tarns and several types of protected ecosystems in mountain and alpine range with rare, endangered, relict and endemic plant and animal species (Vološčuk et al., 1994). Both of the valleys are situated on the south side of the High Tatras. The area of the Velká Studená dolina valley is approximately $9.75 \mathrm{~km}^{2}$ and the Malá Studená dolina valley is approximately $5.42 \mathrm{~km}^{2}$ (Figs 1 and 9).

\section{Geology}

The High Tatras are a part of a long mountain range, which stretches from the Alps to the Himalayas, which was created as a consequence of the collision of lithosphere plates (African, Arabian and Indian) with the edge of the Eurasian continent. As a result, a complicated thrust fold structure was created. The Tatras are typical core mountains, which fall into core mountains zone (Fatra-Tatras area), and thereby represent the most external zone of the internal West Carpathians. 

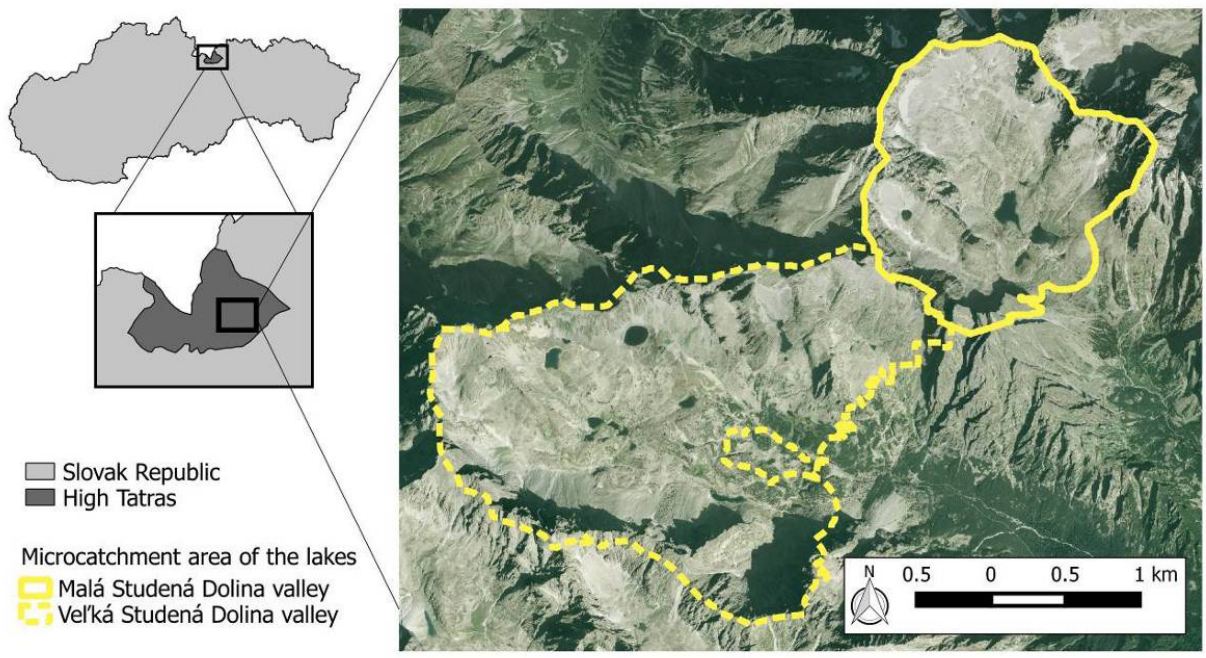

Fig. 1. Location of the High Tatras within the Slovakia (on the left) and location of the Malá Studená dolina valley and Velká Studená dolina valley within the High Tatras, (elaborate: I. Jakab).

Their base is created by metamorphic and volcanic rocks from the Paleozoic era (crystalline-granite core). They create fundament whereon Mesozoic sedimentary rocks (allochthonous complex) are seated and tectonic displaced overlying rocks, which causes geologically older rocks to be found on younger rocks in some areas. It means that the higher the shifted geological unit appears in recent geological composition, the further south her home zone was.

According to Nemčok et al. (1993), Paleozoic granodiorites up to tonalities and local leucocratic granite are in the rock structure of research valleys in a large measure. From quaternary sediments glacial fractions up to boulders backdown moraine sediments are from an older Holocene age. All other types of clastic sediments up to boulders are debris flows, screes, blockfields and rock falls. They are from the Pleistocene-Holocene age.

\section{Geomorphology}

The ends of the Malá Studená dolina valley and Velká Studená dolina valley are glacial cirques (corries). They are the source areas of glaciers, which have the main area in riss glaciation, where they extend to the forefield of the High Tatras (Lukniš, 1973). The formation of the glacial cirque was interrupted by the Würm glaciation (7000-10,000 years ago), which is proved by the moraine sediments and forms of the rock glaciers. Above the glacial cirque are mountain ranges and peaks with a relative elevation difference of 200-600 $\mathrm{m}$, which causes predispositions of the relief energy and potential of the gravitation processes. The areas of the glacial cirque are dissected by the rock stage with an altitude of a 


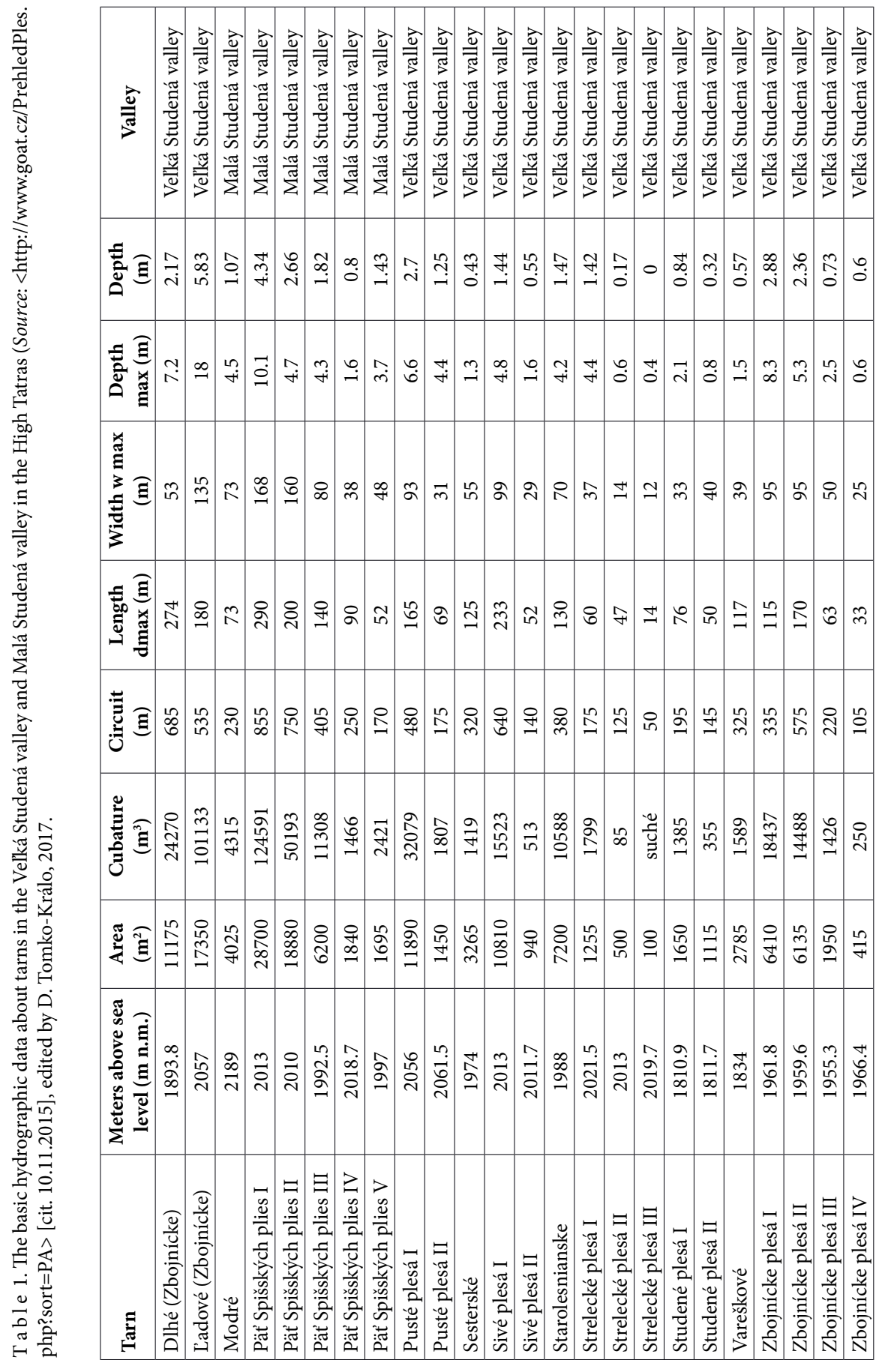


few dozen meters, as it is in the Vel'ká Studená dolina valley, where the highest mountain cirques are more than $2050 \mathrm{~m}$ above sea level and the lower mountain cirques are around 2000 m.a.s.l. The most marked are the rock steps between the glacial cirques and the glacial valleys - furrows with a relative elevation difference up to $300 \mathrm{~m}$. In the postglacial age, massive debris flows located on base of rock walls markedly influenced the morphology of the valleys. The formation of the slopes and their bases was also influenced by processes of rock falls. Debris flow cones deposited as a consequence of water-gravitational processes of debris flows under the gullies. The verification of the erosion glaciers activity are tarns basins, which are preserved in almost every valley of the High Tatras.

\section{Hydrology}

The highest number of tarns (22) (Table 1 and Fig. 9) in the High Tatras is in the Velká Studená dolina valley. With regards to the runoff regime, this area falls into the alpine region and its type is momentary snow (Šimo, Zatko, 2002). The highest is in May and June and the lowest is in January and February. It reaches the accumulation from October to March, eventually in April. Its aquosity is high from April to July. The average annual specific runoff is - according to Lešková and Majerčáková (2002) - more than $401 . \mathrm{s}^{-1} \cdot \mathrm{km}^{-2}$ (one of the highest in Slovakia). The minimal specific runoff is from 3 to $51 . \mathrm{s}^{1} \cdot \mathrm{km}^{-2}$. Maximal specific runoff with a probability of frequency once in a hundred years is 2.8 to $3 \mathrm{~m}^{3} \cdot \mathrm{s}^{-1} \cdot \mathrm{km}^{-2}$. The area of the Vel'ká and Malá Studená dolina valley falls into (Majerčáková, 2002) the river basin of the Poprad river with hydrological balance (since 1931 to 1980): the precipitation was $905 \mathrm{~mm}$, runoff $373 \mathrm{~mm}$, evaporation $532 \mathrm{~mm}$ with runoff coefficient (runoff / precipitation) 0.41 .

The area of the High Tatras falls into (Malík, Švasta, 2002) the hydrogeological crystalline complex region part of the High Tatras.

The high total precipitation and relatively low evaporation means that the Tatras tarns are well supplied with water for a whole year. Transport of water into tarns is in progress mainly as an underwater inflow through debris flows and moraine. Nearly all of the larger tarns have surface streamflow, which takes away excessive water to a drainage network. Therefore, the variations of water levels are small, at an average scope to $50 \mathrm{~cm}$; in extreme events, they don't exceed $100 \mathrm{~cm}$. The most oscillations are in small inland tarns. During the winter period, the surface of water has a minimal level (since December to April). The maximum level is achieved when there are the most precipitations (June and July). Periodical daily measures were practiced only in Štrbské pleso mountain lake for 10 years, from 1951 to 1962.

\section{Climate conditions}

The territory of the Vel'ká and Malá Studená dolina valley falls into the subalpine and alpine level. Lapin et al. (2002) integrates this area into the cold region (C) - with an average temperature of less than $16^{\circ} \mathrm{C}$ in July. Later integrates it into zone C3 - Cold Mountain zone with an average temperature of less than $10{ }^{\circ} \mathrm{C}$ in July. According to the average 
annual values of the climatic index of watering, this territory has overage precipitations around $1000-1200 \mathrm{~mm}$. The average annual value of the radiation index of dryness is approximately 0.55 . The potential evapotranspiration during the average annual rainfall is around $350-400 \mathrm{~mm}$ (Tomlain, 2002). The relative duration of the sun outshine is $37 \%$. The average annual values of the global radiation are 1200-1250 kwh. $\mathrm{m}^{-2}$ (Tomlain, Hrvol, 2002). The average air temperature is $-10{ }^{\circ} \mathrm{C}$ in January and $3.8^{\circ} \mathrm{C}$ in July. The evolution of the average annual air temperature on Skalnaté pleso from 1961 to 2013 is shown in Fig. 2. The average number of summer days is less than 5, and there are more than 169 freezing days (numbers from village Ždiar) (Bochníček et al., 2002). The number of days with snow is more than 250. The average total annual precipitations are more than $2000 \mathrm{~mm}$. The average total precipitations in July are more than $200 \mathrm{~mm}$ and in January more than 90 $\mathrm{mm}$, mostly in the form of snow (Faško, 2002a,b,c,d; Faško et al., 2002). The total annual precipitations over the years 1951-2013 are shown in Fig. 3. In our region, snow cover duration can be estimated as 200-270 days of the year.

The contrast between cold (NE, N, NW) and warm (SE, S, SW) expositions are very visible in these localities. For example, on a warm (SW) slope, the temperature was $15^{\circ} \mathrm{C}$ at a depth of $50 \mathrm{~cm}$ for 20 days in July 1954. On a cold exposition (NE), it was only seven days.

The wind influences differences in thickness of the snow cover, soil temperature and especially evaporation from the soil and thus humidity conditions. Concerning its effectiveness on vegetation, wind has great mechanical impact, either direct impact or as driftsnow. Wind direction is very often north-western. Above the timber-line wind speed also increases. For example, on Chopok (it is a peak in the Low Tatras, 2024 m. a. s. 1.), the wind speed is $9.8 \mathrm{~m} . \mathrm{s}^{-1}$, in the nearby town Liptovský Mikuláš. The speed is only $1.2 \mathrm{~m} . \mathrm{s}^{-1}$. It makes ecological conditions and exposition clime worse. Windward and leeward sides become more important. The influence of climatic factor is considerably multiplied or debilitated by local relief (Š́ly, 2006).

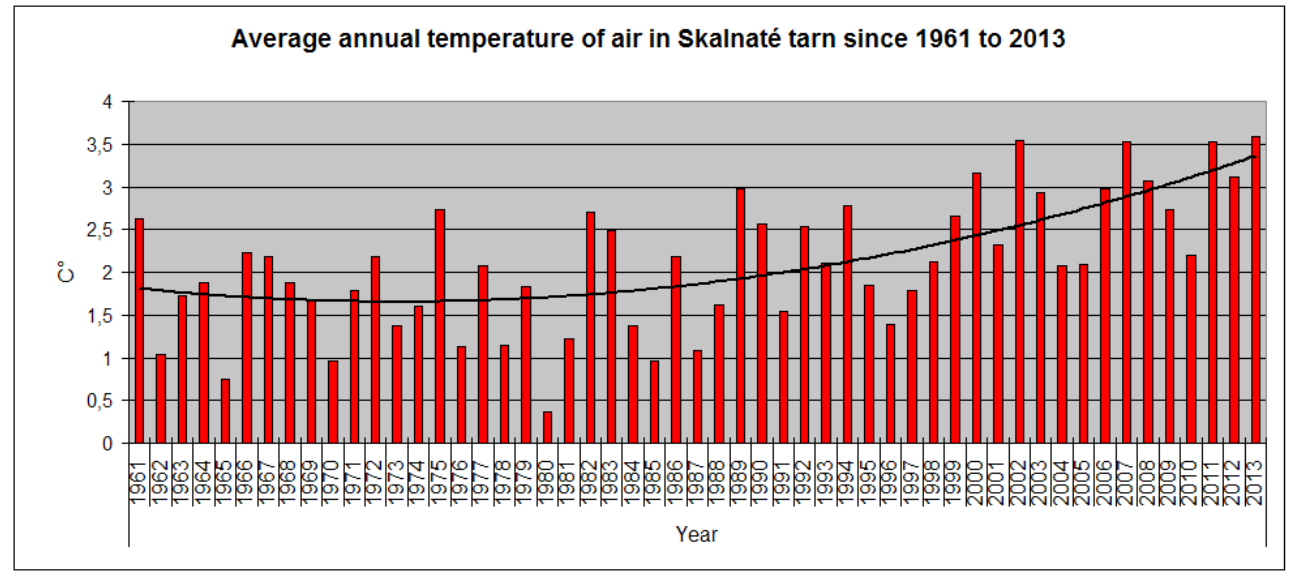

Fig. 2. Average annual temperature of the air in Skalnaté tarn since 1961 to 2013. Source: SHMI, elaborate: D. Tomko-Králo, 2014. 


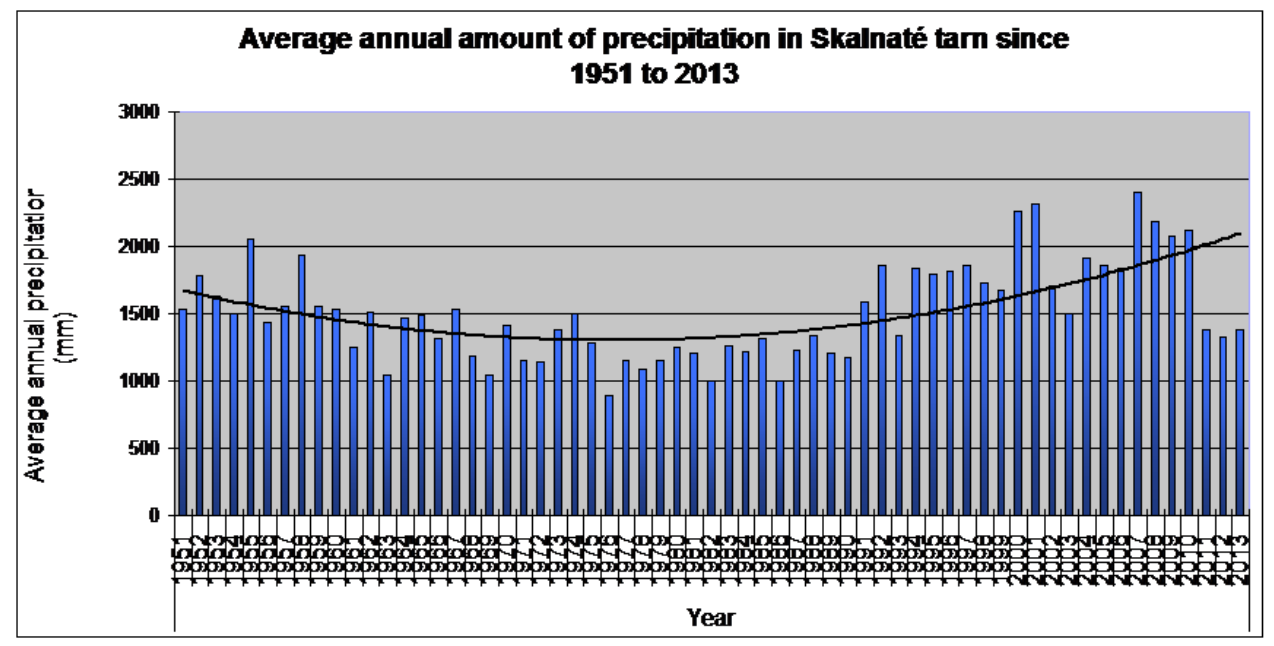

Fig. 3. Average annual amount of the precipitation in the Skalnaté tarn from 1951 to 2013. Source: SHMI, elaborate: D. Tomko-Králo, 2014.

Soils

In our research area are mostly soils of alpine and subalpine level. In Slovakia it is approximately $450 \mathrm{~km}^{2}$, which is about $1 \%$ of the total area.

Alpine soils are on the edge of an ecological-edaphic string. That is the reason why they react sensitively to changes. The expected global climate change can be reflected in future decades in their production or hydric function. If the average temperature amplifies by $2-3{ }^{\circ} \mathrm{C}$, it could mean an altitude difference of $300-500 \mathrm{~m}$, which can cause modification of the vegetation level.

It is well known that soils used to be horizontal and vertical variable. This is specially the same with alpine soils (Šály, 2006).

Types of mainly soil formations in the Velká Studena dolina valley and Malá Studená dolina valley (Šály, 2006):

A. Podzols soils (iron-humus), B. Podzols cambial, C. Podzols organic, D. Rankers organic, E. Rankers cambisolic, F. Rankers podzolic, G. Leptosol modal silicate, H. Fluvisol modal.

Debris flow hazards and their relation to clime changes and extreme rainfalls events

A lot of authors focused on debris flows like natural hazards (e.g. Glade, 2005; Jakob, Hungr, 2005; Hürlimann et al., 2006). After Hürlimann et al. (2006) two types of assessment studies on a regional scale and studies on a local scale were conducted. The majority of authors study debris flow hazard on a regional scale with the geographic information system (GIS), in combination with statistical analysis, simple dynamic methods and interpretation of satellite 
images or aerial photographs (Mark, Ellen, 1995; Iverson et al., 1998; Guzzetti et al., 1999; Hofmeister et al., 2002; Lin et al., 2002; Huggel et al., 2003; Liu, Lei, 2003; Vallance et al., 2003; Pallas et al., 2004). On a local scale, comprehensive field work is necessary to determine the hazard in the debris flows' deposition areas (García et al., 2003; Chau, Lo, 2004; Pasuto, Soldati, 2004).

There is a close relationship between extreme precipitation events and the occurrence of debris flows as some authors pointed out (Kapusta et al. (2010), Fussgänger and Jadroň (2001), Kopecký (2001), Chen (2006) and Larsen et al. (2006). It can be connected with climate changes (Larsson, 1982; Addison, 1987; Zimmermann, Haeberli, 1992; Deline et al., 2004; Jomelli, 2004; Pavlova, 2011). Pavlova (2014) confirms significant climate changes observed in the two regions (southern and northern) of the French Alps over the last four decades (1970-2005). It caused changes in the environment, including debris flows activity. They examined the links between DF activity and climate parameters.

Some authors developed an algorithm for the objective and reproducible reconstruction of rainfall events and of rainfall conditions responsible for landslides (Melillo et al., 2016).

According to Kotarba (2005), debris flows (spływ gruzowy) are geomorphological processes and forms, which are created by highly atmospheric rainfalls in landwaste cover. Rainfalls, which have an intensity of $>1 \mathrm{~mm} / \mathrm{min}$ and yield $40 \mathrm{~mm}$ per hour, speed up the formation of debris material on the slopes of the Tatras (Fig. 4). In the Alps, flows which had 400 000-500 $000 \mathrm{~m}^{3}$, were registered; in the Tatras it was only $25000 \mathrm{~m}^{3}$. In Scotland and Scandinavia it was only $100-350 \mathrm{~m}^{3}$. Their scale is dependent on morphological and lithological conditions. In this case, it is important to know landwaste cover.

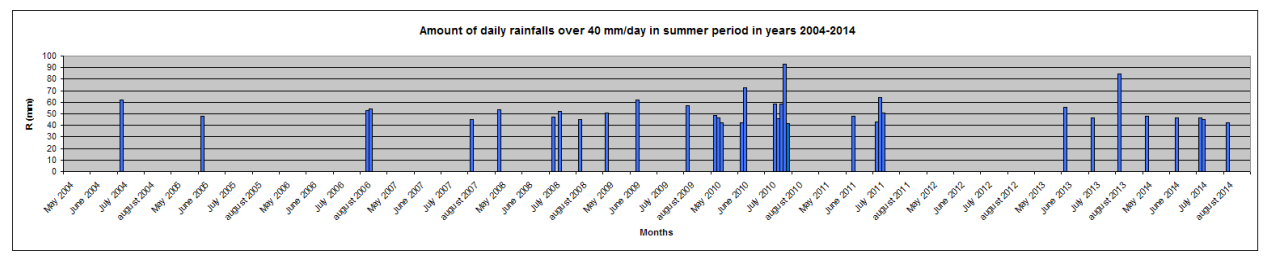

Fig. 4. Frequency of daily rainfall of more than $40 \mathrm{~mm} /$ day in the summer period over the years 2004-2014 (D. Tomko-Králo, 2014).

The statistical measurements show that intensity of rainfalls $60-80 \mathrm{~mm}$ / hour occur with a probability of $1 \%$ once in 100 years. But intensity of rainfalls at $40 \mathrm{~mm}$ / hour can appear with probability of $10 \%$ once in 10 years. During the last seven years, the intensity of extreme rainfalls has increased in comparison to the older measurement, which was realized by Niedźwiedz (2003). According to Kotarba (2005), we can observe the transition to a more humid climate in the Tatras since 1995. It is necessary to mention that the same amount and intensity of precipitations do not have to cause the geomorphological process of the same scale.

Data shows that the scale of debris form depends mainly on local topography - energy of relief, length of slope, their segmentation in system of valley, the area of slope, which was in- 
tervened by rainfalls, the type of cover and especially the extent of their connection. It could influence the scale of debris flows.

Mergilli et al. (2011) simulated debris flows on a small catchment scale realized in GRASS GIS. The goal was to reconstruct past debris flows in selected small catchments and to evaluate the potentials and limitations of the model components. GRASS GIS appeared highly suitable for this task as its modular structure allows for the implementation of complex algorithms due to the support of the $\mathrm{C}$ programming language. It was also one of the reasons why we used this program in our work.

\section{Silting up of tarns in the Tatra Mts}

Interest towards the Tatras tarns has increased since 1875. At that time, the first detailed maps of the tarns, which were easily available, started to appear (Houdek, 1943). However, detailed mapping of the tarns by tacheometry between the First and the Second World War was not exact enough. O. Dub came out from this mapping, when he created the first Slovak limnology guide (1953). These negatives were eliminated until new mapping began between the years 1961-1964, by a collaboration between the Research station of TANAP (Tatra National Park), Hydrology Institute of SAS (Slovak Academy of Science) and Department of Geodesy STU (Slovak University of Technology) (Gregor, 1965; Pacl, 1999, Gregor, Pacl, 2003; Gregor, 2005). During the next few years, the results of morphometry were completed with bathymetry and hydrology research, and the exact estimate of tarns altitudes was realized up to a definitive determination of coordinating and vertical surveying system of the Slovak Republic.

Gregor and Pacl $(2003,2004,2005)$ state that some Tatras tarns are progressively backfilled and silted up by debris cone, debris rock and also recently silted up by fine debris and abrasive sand from debris cone and thereby the general area and volume of the tarns are diminished. From many forms and types of backfilling and silting up, they state that there exists two main types of backfilling: (1) deposits of abrasive debris are transported by avalanches and landslides from scarp slopes, which have a slope gradient of more than 50\% (e.g., Zmrzlé pleso tarn); (2) depositions of landwastes mostly transported by water and finegrained fluvial deposits from debris cone, which have a slope gradient to $20 \%$ in confluent area (e.g., Zelené pleso tarn, Kačacie pleso tarn and Kolové pleso tarn).

Šobr and Česák (2006) from CU in Prague studied nine Tatras tarns using the bathymetric measurements. Among others it was also Pusté, Ladové and Vyšné Sesterské tarn in the Velká Studená valley. During the research, they used the air raft on which they had an echo locator and they measured the depth every $5 \mathrm{~m}$. After measuring, they obtained bathymetric maps of Ladové tarn, Pusté tarn and Vyšné Sesterské tarn; in the process they used MapInfo and Surfer computer programs, where they applied the Krigings' method.

Hreško et al. (2012) studied the tarns in the High Tatras, focusing on the effects of morphodynamic changes in the surroundings of tarns and on their silting up. The first tarn was Popradské tarn, which represents a type of tarn silted up by fluvial delta with an advanced point of the succession of the vegetation. Čierne Javorové tarn was silted up by debris flows, which had on the end rock-sand delta. Then it was Kolové tarn, which was silted up by falling 
of rock blocks and debris flow and the last was Malé Žabie Javorové tarn, which represents an eclipse of the tarn in the final stage.

\section{Materials and methods}

For the modelling of potential inclination of the tarn basins on deposition by water-induced processes, we have used the formula:

Formula 1: $\mathrm{Rp}=\mathrm{Lc}{ }^{*} \mathrm{~s}^{*} \mathrm{Cr}$

where $\mathrm{Rp}$ is the potential of the depositions, which we can calculate as the multiplication of three factors: landscape cover (Lc), slope of relief (s) and curvature of relief (Cr). The preparation of base layers, their creation (digitalization) and spatial analyses (morphometric spatial analyses, reclassification of dates and map algebra) were done with GRASS GIS software (Grass Development team, 2011). We used ArcGIS 9.3 software for cartographical presentation and creation of the map outputs.

\section{Curvature of the relief}

The curvature factor of the relief determines the deceleration or acceleration of the water in land and enters to evaluation of potential deposition of material by running water. We expressed the curvature by overlapping curvature profile and tangential curvature, and after that we reclassified them to three values. The value of 0.5 was matched with convex shapes, where the values of both curvatures calculated by function $r$ slope aspect in GRASS GIS program were in the positive numbers. The value of 2 was achieved in this case, when at least one layer from the input dates of the curvature have a concave character; it means that values were moving in negative numbers. We added factor with a value of 1 to direct shapes of the relief with both values of curvature with the value of 0 .

We created the curvature model of the relief on the basis of curving of the relief from DEM of the relief Velká and Malá Studená dolina valley in GRASS GISS program (Grass Development Team, 2011). DEM has been prepared by Kotarba et al. (2013) too. We used raster function slope and aspect, and its two functions: (1) profile curvature raster map - created normal curvature, facing the fall line we named her krivost1 and (2) tangential curvature raster map - created horizontal (facing the contour or tangential) curvature.

Krcho (1990) understands the normal curvature $\omega \omega=\left(K_{n}\right)$ (in our case krivost 1 ) of the topographical area of the earth relief facing the fall line in each of its point $A^{\prime}{ }_{i}{ }^{*} \varepsilon \mathrm{E}^{*}{ }_{R F}$ as curvature of the normal cut in this point speculated like intersection of topographical area with plane $\sigma_{N n}$ containing normal line $N$ to topographical area and tangent $n$ to its fall line, so plane of cut $\sigma_{N n}$ is perpendicular to tangent plane to topographic area in specific point $A^{\prime}{ }_{i}$ ${ }^{\star} \varepsilon \mathrm{E}_{R F}^{\star}$. The result was Fig. 5 (on the left).
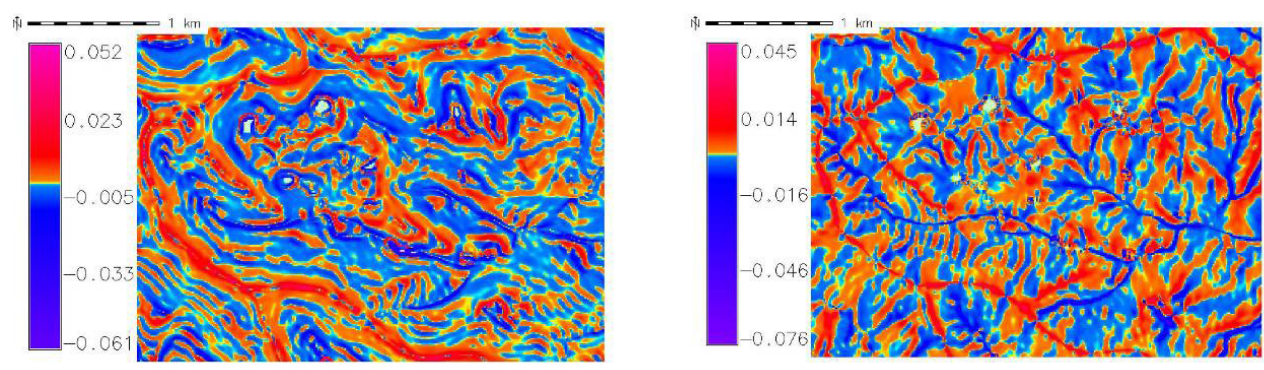

Fig. 5. Examples of maps of the normal curvature (on the left) and horizontal curvature (on the right) of the Velká Studená dolina valley, map was created in the Grass Gis ver. 6.4.1 program. The same map was created for the Malá Sudená dolina valley too (D. Tomko-Králo, 2014). 


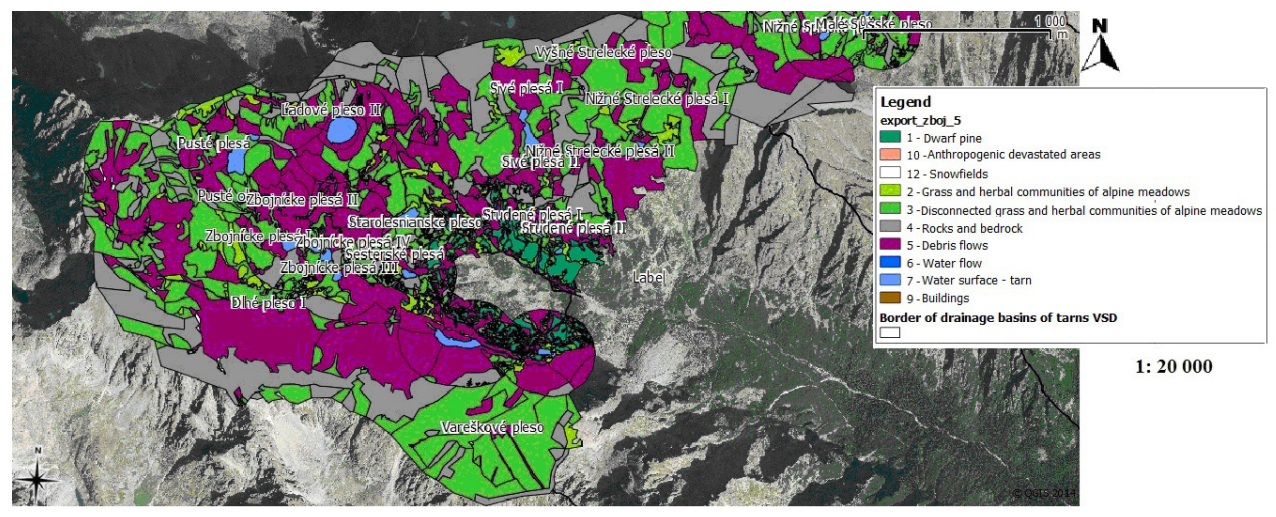

Fig. 6. Example of the landcover layer, which was not reclassified. Vel'ká Studená dolina valley (Tomko-Králo, 2014).

The same author understands the horizontal curvature (tangential) to be the curvature of the topographical area of the georelief facing the contour line in the specific point $A^{\prime}{ }_{i}^{*} \varepsilon \mathrm{E}^{*}{ }_{R F}$. And the result was Fig. 5 (on the right).

\section{Land cover}

The map layer of the land cover (Fig. 6) was created in Quantum GIS ver. 1. 7. 0 (2010) on the basis of aerial photographs (2004) (Google Earth, Image@2014 Eurosense/Geodis Slovakia). To make the research exact, we chose 12 elements (table 2), which represent the character of the microcatchment area of the Malá and Velká Studená dolina valley. We assigned ID numbers to individual components of the land (Table 2). Thereafter we added factor of the potential water deposition of the land cover components to each ID, on the basis of the particular impact on silting up or backfilling of the tarns as the foundation of the creation reclassified map of the land cover, also with additional factors of retention (Fig. 7).

$\mathrm{T}$ a b l e 2. ID numbers of the individual components of the land and their factor of the potential water deposition of the land cover components (D. Tomko-Králo, 2014).

\begin{tabular}{|l|l|c|}
\hline ID & Land cover component & $\begin{array}{c}\text { Factor of potential water deposition of the } \\
\text { land cover components }\end{array}$ \\
\hline 1 & Dwarf-pine & 0.7 \\
\hline 2 & Grass and herbal communities of alpine meadows & 0.4 \\
\hline 3 & $\begin{array}{l}\text { Disconnected grass and herbal communities of al- } \\
\text { pine meadows }\end{array}$ & 0.3 \\
\hline 4 & Rocks and bedrock & 0.1 \\
\hline 5 & Debris flows & 0.6 \\
\hline 6 & Water flow & 1.0 \\
\hline 7 & Water surface - tarn & 1.0 \\
\hline 8 & Forest / individual trees & 0.9 \\
\hline 9 & Buildings & 0.1 \\
\hline 10 & $\begin{array}{l}\text { Anthropogenic devastated areas (paths, trampled ar- } \\
\text { eas around chalet) }\end{array}$ & 0.2 \\
\hline 11 & Debris flows from recent landslides & 0.6 \\
\hline 12 & Snowfields & 1.0 \\
\hline
\end{tabular}




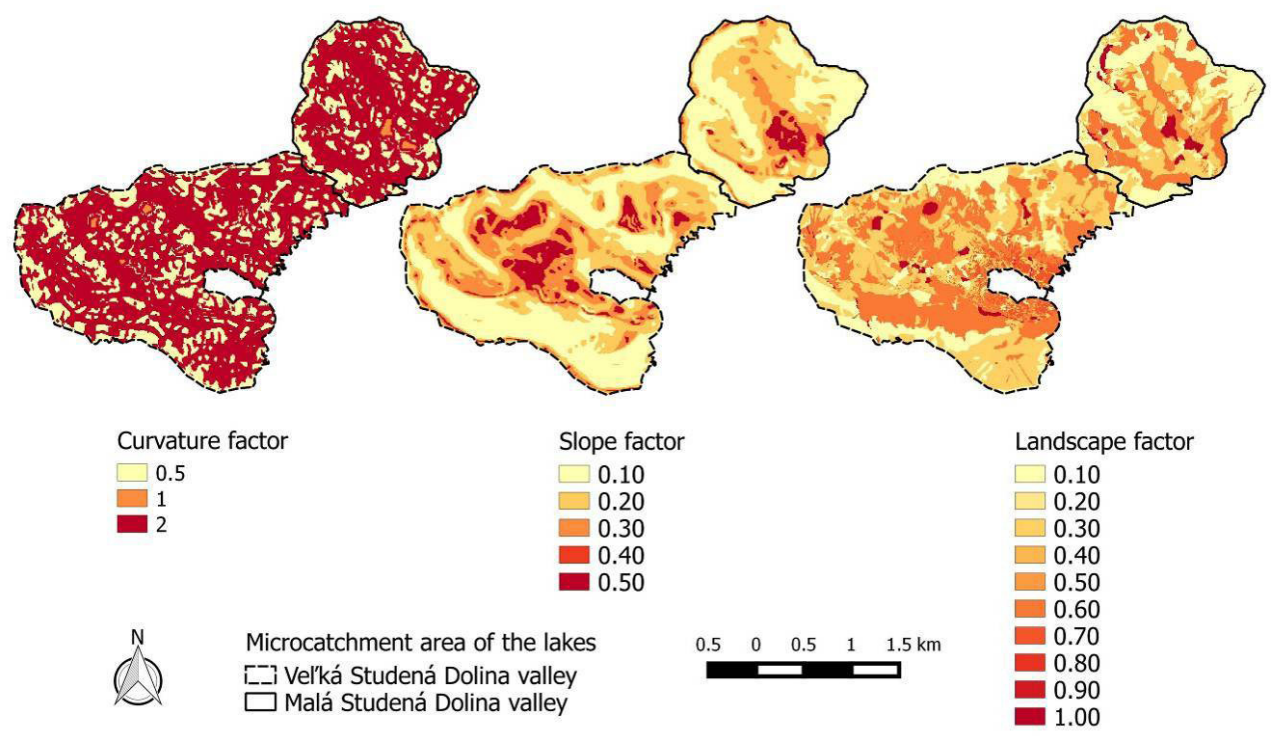

Fig. 7. Reclassified maps of the land cover, slope and curvature of the relief factors (Tomko-Králo, 2014, modified by I. Jakab).

\section{Slope of relief}

Slope of the relief, profile curvature and tangential curvature were calculated from the digital elevation model (DEM) of the relief Velká and Malá Studená dolina valley (created by Esprit company, 2013) on a scale of 1:10 000 and with $10 \mathrm{~m}$ pixel resolution. We created the model of slope relief with the "slope" function in GRASS GIS ver. 6. 4. 1. program (2011). We scaled the slope (Table 3) to four classes thanks to the point values on the basis of the expert weight rating and assigned factor of the slope on water retention, which indirectly shows how big an impact the slope has on the potential of threat by silting up and backfilling of the tarns (Fig. 7).

Particular categories as slope of the relief, curvature of the relief and land cover were assigned the values of the factors, which were entered to the calculation of potential water-induced deposition of the materials.

Then we multiplied all of these three layers (land cover, slope and curvature) using the map calculator in GRASS GIS program and the result was the digital map of the inclination to deposit (backfilling and silting up), which is induced by water processes in the Velká Studená dolina valley and Malá Studená dolina valley (Fig. 8 and Table 4).

T a b l e 3. The values of the slope factor of the relief (J. Hreško, 2014).

\begin{tabular}{|l|c|}
\hline Slope & Slope factor \\
\hline From $0^{\circ}$ to $8^{\circ}$ & 0.5 \\
\hline From $8^{\circ}$ to $20^{\circ}$ & 0.3 \\
\hline From $20^{\circ}$ to $34^{\circ}$ & 0.2 \\
\hline From $34^{\circ}$ to $90^{\circ}$ & 0.1 \\
\hline
\end{tabular}




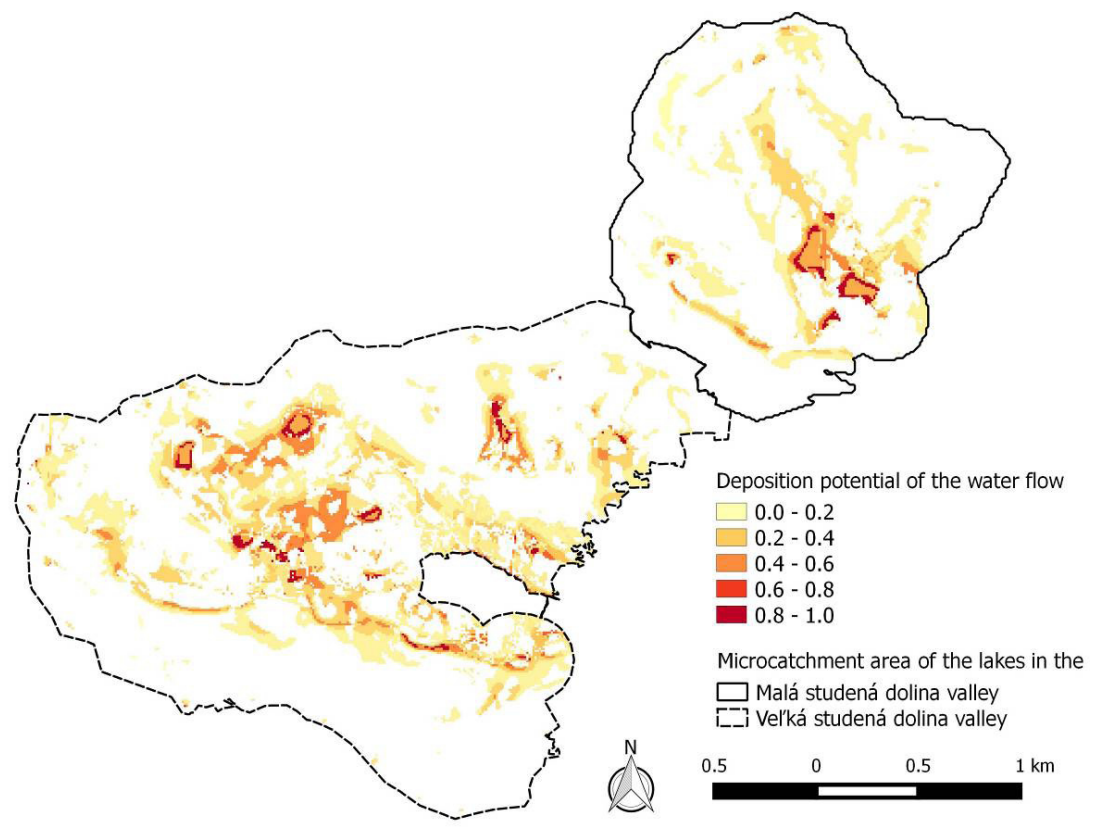

Fig. 8. Map of the inclination to deposit (backfilling and silting up), which is induced by water processes in the Vel'ká Studená dolina valley and Malá Studená dolina valley (Tomko-Králo, 2014 modified by I. Jakab).

$\mathrm{T} \mathrm{a} \mathrm{b}$ le 4 . The areas of the categories water induced potential deposition of material.

\begin{tabular}{|l|c|c|l|c|c|}
\hline \multicolumn{3}{|l|}{ Velká Studená dolina valley basin (left side) } & \multicolumn{3}{|l|}{ Malá Studená valley basin (right side) } \\
\hline $\begin{array}{l}\text { Deposition potential } \\
\text { of the water flow }\end{array}$ & Area $\left(\mathbf{m}^{2}\right)$ & $\%$ & $\begin{array}{l}\text { Deposition potential } \\
\text { of the water flow }\end{array}$ & Area $\left.\mathbf{( m}^{2}\right)$ & $\%$ \\
\hline $0.0-0.2$ & 3790225 & 74.0 & $0.0-0.2$ & 2029500 & 79.4 \\
\hline $0.2-0.4$ & 1051462 & 20.6 & $0.2-0.4$ & 430200 & 16.8 \\
\hline $0.4-0.6$ & 66901 & 1.3 & $0.4-0.6$ & 37800 & 1.5 \\
\hline $0.6-0.8$ & 172481 & 3.4 & $0.6-0.8$ & 35300 & 1.4 \\
\hline $0.8-1$ & 37617 & 0.7 & $0.8-1$ & 20700 & 0.8 \\
\hline
\end{tabular}

\section{Results and discussion}

Water-induced potential deposition of the material in research valleys was determined as the product of factor values according to the formula 1 by which we created the spatial model of the areal distribution with an inclination to backfilling and silting up by running water and water-induced processes. We verified the results on many localities by terrain research. The obtained information showed that the model is the appropriate instrument for the expression of the water-induced potential deposition of the material in the microcatchments of the tarns 
in the examined valleys. The map model also allocated the areas of former tarn basins, which were backfilled in the past and today represent local erosion bases for surface streamflow.

Up to now, research of the mountain lake tarns in the Malá and Velká Studená dolina valley have shown a direct impact of morphodynamic processes and their source areas on successive fulfilling of tarn basins, which was also confirmed in several works (Gregor, Pacl, 2003, 2004; Hreško et al., 2012) (Fig. 9). We have also found out that apart from the gravitational and the water-gravitational processes, the surface and subsurface streamflow of rainfall water including melted water from snow fields also takes part in the process of silting up of tarns. As Gregor and Pacl (2004) pointed out, a lot of the tarns are silted up by washed out soft grained fractions from clastics up to boulders debris slopes and cones also from the impact of the hillsides and direct effect of the processes.

In the microcatchment of the Velká and Malá Studená dolina valley, we confirmed conformity of the model with contemporary processes of the deposition under the influence of

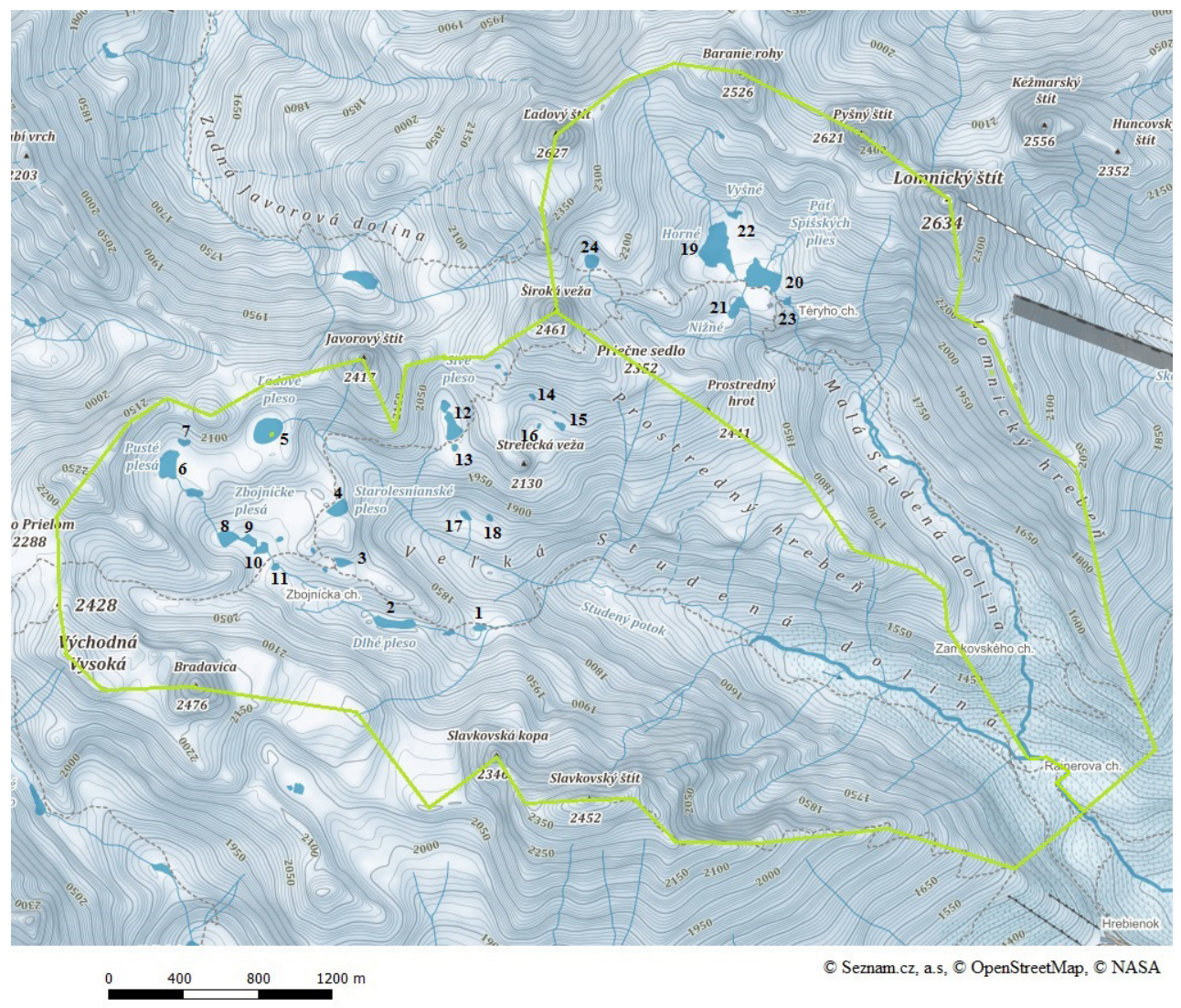

Fig. 9. Areal distribution of the tarns in the Velká and Malá Studená valley. The number of the tarns is corresponding with Table 1 (T)TopGis s.r.o, (CSeznam.cz, a.s, 2012 (modified: Tomko-Králo, 2016). 
the fluvial-proluvial activity of the brooks, which connect cascade-arranged tarns and transport softer grained fractions of the sediments from the higher tarns to the lower. The examples of this group are Pusté tarns and Zbojnícke tarns along the southern border of the valley. The higher situated tarn basin of Sivé tarn under the massif of Javor peak (2417 m n. m.) (Fig. 10) shows high potential of the deposition as a consequence of the debris gravitational and debris flow cones accumulations, which fulfilled the whole end of the kettle and have a tendency for the next extension (Fig. 10).

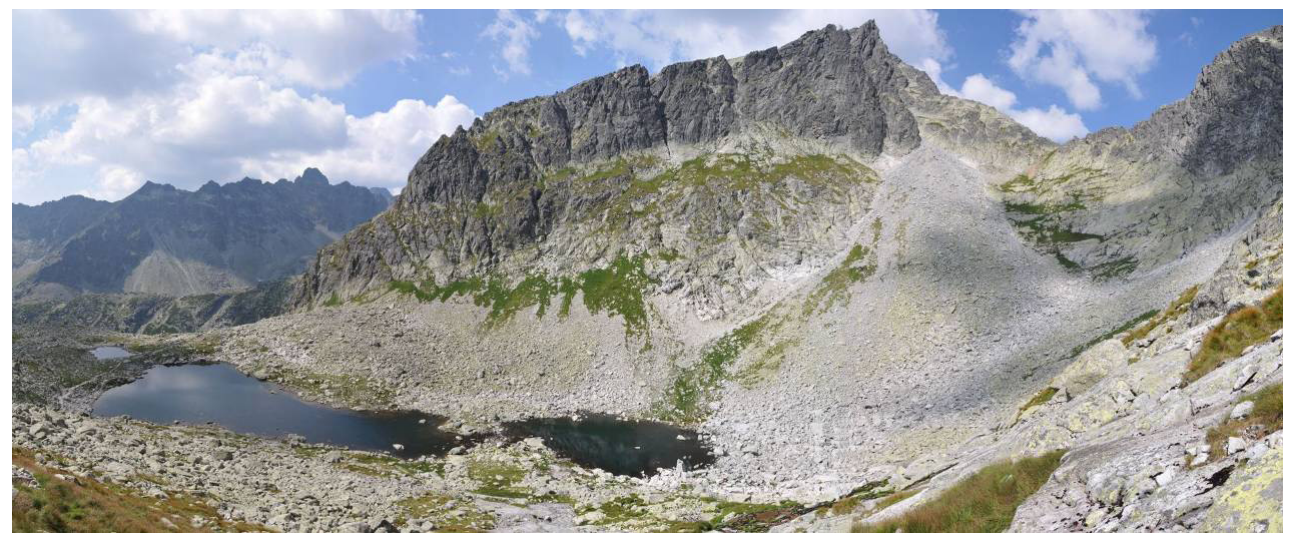

Fig. 10. Large debris-gravitational cone on slope of Javorový peak (2417 m n. m.), which fulfilled the whole end of the tarn basin of Vyšné Sivé tarn (1990 m n. m.) (Photo: J. Hreško, 2015).

In the case of other tarns, the results are close to the real situation. For example, Ladové tarn, Nižné Strelecké tarn and the lowest situated Zbojnícke tarn. In some cases, the model shows positive deposition, but our research did not confirm it visually. Near the Vareškove tarn, the model does not correspond in the case of the largest debris cone with blockfield, which falls into the tarn from the east side and only in a small measure shows the potential of fluvial-proluvial cone (Figs 11 and 12).

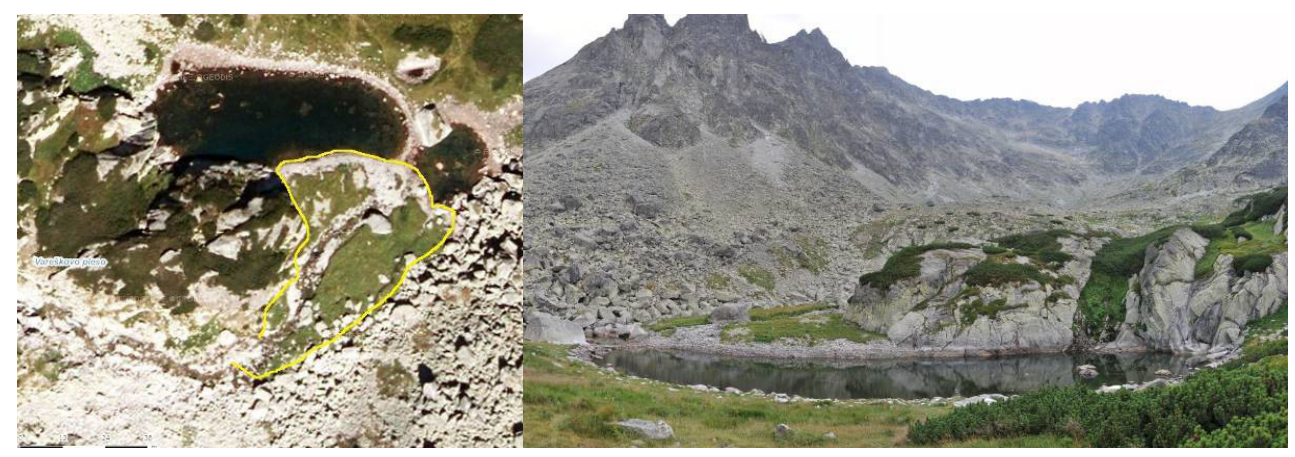

Fig. 11. and 12. Vareškove tarn (1840 m n.m.) became extinct progressively by accumulation of fluvial cone with consecutive wash out of the soft grained fractions. (Photo: J. Hreško, 2015). 
In the microcatchment of the Malá Studená valley, the model correctly shows the deposition in the surroundings of the highest situated tarn in the High Tatras-Modré tarn (2157 m.a.s.l.). This basin is situated at the end part of glacial cirque under the south hillslope of Malý Ladový peak (2603 m.a.s.l.). From this part of the microcatchment, the large accumulations of debris cones with high recent production of clastics material fell down. From saddleback Sedielko (2200 m.a.s.l.) between Široká veža (2462 m.a.s.l.) and Malý Ladový peak (2603 m.a.s.l.) large cone with bifurcated debris flows falls into the tarn basin of Modré tarn. These flows are a source of anything from tiny fragments to sand material from a tectonically predisposed mylonits disturbance zone (Fig. 13).

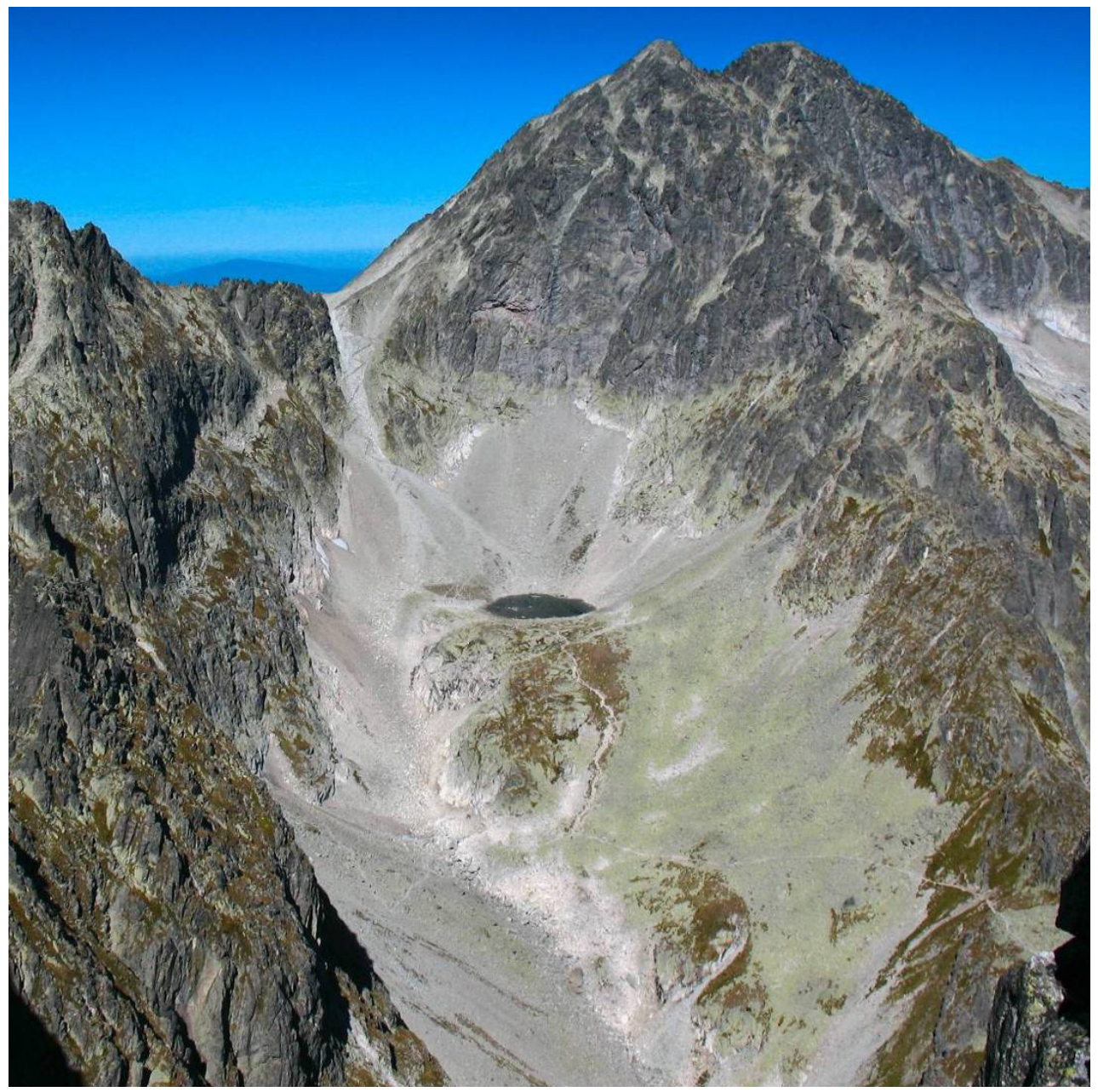

Fig. 13. Modré tarn: the highest situated tarn of the High Tatras. Its evolution is markedly limited by accumulation of the clastics material from rock gullies and debris flows from tectonically predisposed saddleback. (Photo: M. Maličký, 2012). 
The model thereafter faithfully showed the backfilling of Vel'ké Spišské tarn (n. 19 in Fig. 9) from the south-western side, where a lot of boulders-gravitational flows and rock falls flow into the tarn or from the northern side, where boulder-gravitational flows get into the tarn, but they do not have contemporary activity (Fig. 14). The model corresponds also with a large alluvial cone, which falls into Prostredné Spišské tarn (n. 20 in Fig. 9) from the north-eastern side. In Malé Spišské tarn, the model correctly did not show increased factors of threat by backfilling or silting up, which corresponds with the small area of river-basin and also with the long-lasting occurrence of a snow field, which does not produce heavy water outflow (Figs 14 and 15). On the other side, when the water stage is higher or rainfalls are heavier, the resource of deposition could be fluvial-accumulation activity of the water stream, which it runs into from the higher situated Velké Spišské tarn, with a higher potential of material deposition.

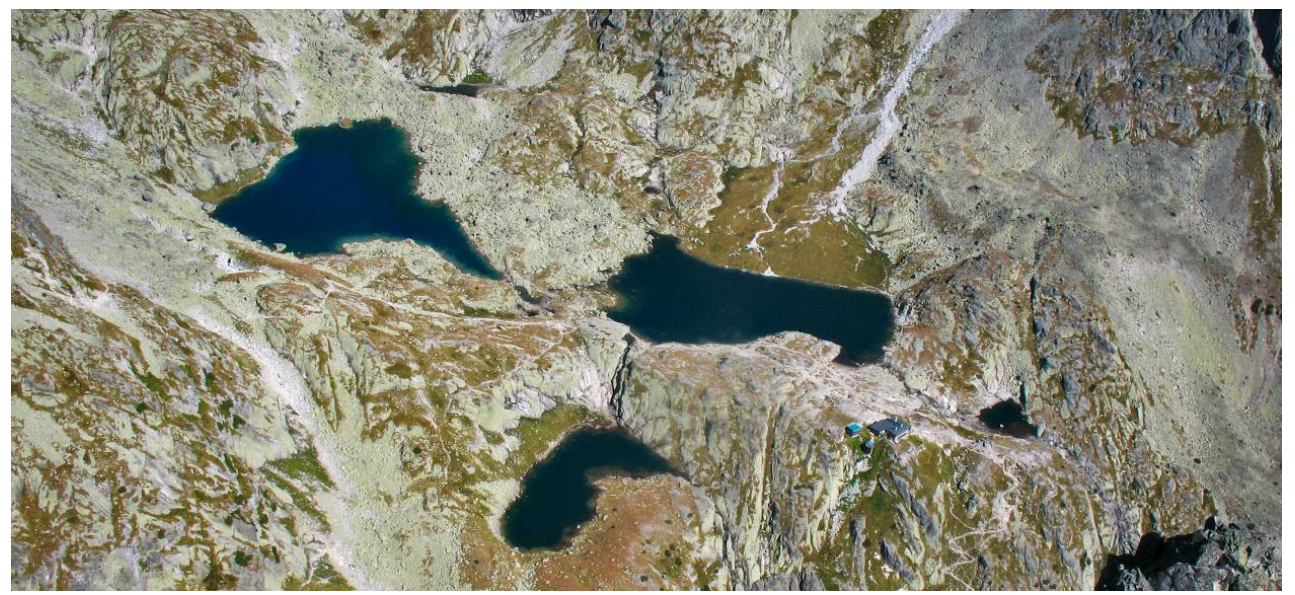

Fig. 14. Velké Spišské tarn, (on the left), Prostredné Spišské tarn (in the middle), Nižné Spišské tarn on the right. Malá Studená valley. (M. Maličký, 2012).

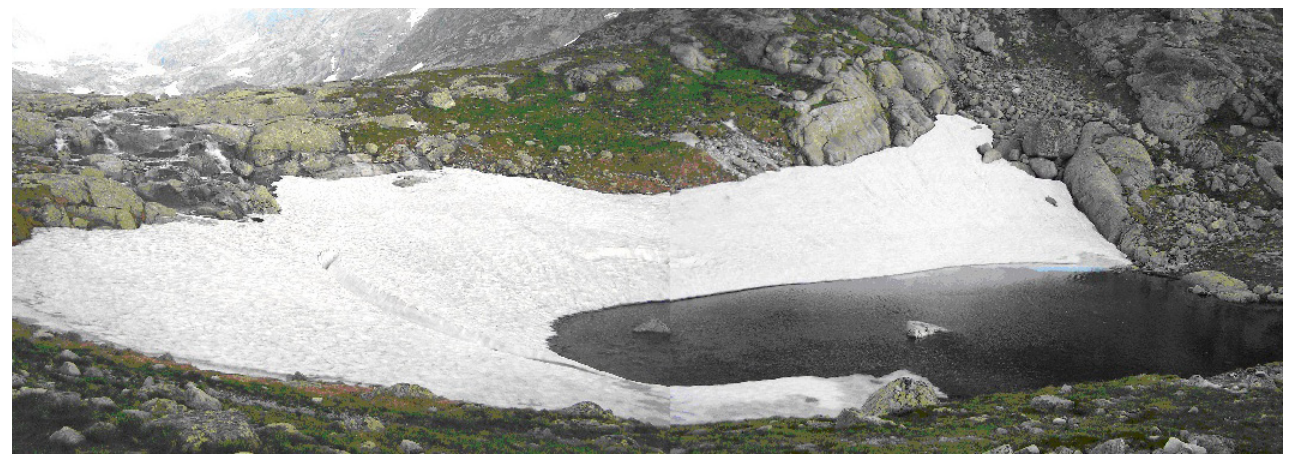

Fig. 15. Malé Spišské tarn situated under Vel'ké Spišské tarn. Malá Studená dolina valley. (D. Tomko-Králo, 2012). 
Near Nižné Spišské tarn (n. 21 in Fig. 9), the model showed the increased factor of the backfilling in the south and intermittently in the north side; however, today the tarn is not endangered by direct backfillng or silting up, because the near land cover consists of alpine grasslands (Fig. 14).

\section{Conclusion}

In the article, we referred to one of approaches which expresses the potential susceptibility of material deposition in the microcatchments of the tarns in the High Tatras mountains. We created a model for glacial cirque areas of two valleys with a relatively large representation of the tarns at different relief positions, which was also verified by the field survey. We confirmed the premise that the dominant factors of possible backfilling and silting up are morfometrical parameters of the relief and character of the land cover. The field survey pointed out that important factors of the aerial distribution of material and its deposition in the tarns are also positional attributes of the relief and subsequently other processes of the alpine environment.

We consider relevant mainly avalanches, processes of nivation connected with the occurrence of the long-term snow fields and cumulative effects of the slope-gravitational and water-gravitational processes. By comparing the results of the model with the real state of the material deposition in the tarns, we found out that the model also allows its use in the other areas of declacial valleys of the Tatras with satisfactory exactness. Regarding the complicated structure of the relief, we consider it essential to use more precise digital sources including the digital model of the terrain, 3D scanner, or remote sensing technologies (DPZ) like detailed photos with the use of a drone. Precise sources and technologies could allow a more accurate identification of deposition of the material, changes of the tarns shore line, but also the demarcation of extinct tarn basis areas. In the same way, it is necessary to focus on long repeated research of the evolution of the tarns with continual measuring of the meteorological factors in the context of the changeable climate conditions. During the last ten years in the area of the High Tatras, extreme rainfalls during the summer period, which activate the formation of debris flows and accelerate the processes of wash out of the soft-grained fractions in the shore lines of the tarns have become evident.

\section{Acknowledgements}

This paper has been produced under the scientific project KEGA - 025UKF-4/2015 - Vývoj a zmeny archetypov krajiny Slovenska (Development and archetypes changes of landcover in Slovakia) and APVV-0669-11 Atlas archetypov krajiny Slovenska (Atlas of archetypes of the landcover in Slovakia).

\section{References}

Addison, K. (1987). Debris flow during intense rainfall in Snowdonia, North Wales: a preliminary survey. Earth Surface Processes and Landforms, 12(5), 561-566. DOI: 10.1002/esp.3290120513.

Bochníček, O., Lapin, M. \& Soták Š. (2002). Priemerný ročný počet vykurovacích dní, letných a mrazových dní. In Atlas krajiny Slovenskej republiky (p. 98). Bratislava: MŽP SR, Banská Štiavnica: Esprit.

Chau, K.T. \& Lo K.H. (2004). Hazard assessment of debris flows for Leung King Estate of Hong Kong by incorporat- 
ing GIS with numerical simulations. Natural Hazards and Earth System Science, 4(1), 103-116.

Chen, H. (2006). Controlling factors of hazardous debris flow in Taiwan. Quarternary International, 147, 3-15. DOI: 10.1016/j.quaint.2005.09.002.

Deline, P., Chiarle, M. \& Mortara G. (2004). The July 2003 Frebouge debris flows (Mont Blanc Massif, Valley of Acosta, Italy): Water pocket outburst flood and ice avalanche damming. Geografia Fisica e Dinamica Quaternaria, 27(2), 107-111.

Esprit s.r.o. (2013). Mapa digitálneho modelu reliéfu, mierka 1: 10 000. Banská Štiavnica: Esprit.

Faško, P. \& Štastný P. (2002a). Priemerné ročné úhrny zrážok. In Atlas krajiny Slovenskej republiky (p. 99). Bratislava: MŽP SR, Banská Štiavnica: Esprit.

Faško, P. \& Štastný P. (2002b). Absolútne maximum mesačných a denných úhrnov zrážok. In Atlas krajiny Slovenskej republiky (p. 99). Bratislava: MŽP SR, Banská Štiavnica: Esprit.

Faško, P. \& Štastný P. (2002c). Priemerné úhrny zrážok v januári. In Atlas krajiny Slovenskej republiky (p. 99). Bratislava: MŽP SR, Banská Štiavnica: Esprit.

Faško, P. \& Štastný P. (2002d). Priemerné úhrny zrážok v júli. In Atlas krajiny Slovenskej republiky (p. 99). Bratislava: MŽP SR, Banská Štiavnica: Esprit.

Faško, P., Handžák, Š. \& Šrámková N. (2002). Počet dní so snehovou pokrývkou a jej priemerná výška. In Atlas krajiny Slovenskej republiky (p. 99). Bratislava: MŽP SR, Banská Štiavnica: Esprit.

Fussgänger, E. \& Jadroň D. (2001). Vplyv súčasných klimatických pomerov na vývoj svahových gravitačných pohybov. In Geológia a životné prostredie: Zborník referátov z 2. konferencie (pp. 15-18). Bratislava: Štátny geologický ústav D. Štúra.

García, R., López, J.L., Noya, M., Bello, M.E., Bello, M.T., González, N., Chang, S.Y., Paredes, G., Vivas, M.I. \& O'Brien J.S. (2003). Hazard mapping for debris-flow events debris flows and warning road traffic at in the alluvial fans of northern Venezuela bridges susceptible to debris-flow. In D. Rickenmann \& C. Chen (Eds.), $3 r d$ Int. Conf. on Debris-Flow Hazards Mitigation (pp. 589-599). Rotterdam: Millpress.

Glade, T. (2005). Linking debris-flow hazard assessments with geomorphology. Geomorphology, 66(1-4), 189-213. DOI: 10.1016/j.geomorph.2004.09.023.

Guzzetti, F., Carrara, A., Cardinali, M. \& Reichenbach P. (1999). Landslide hazard evaluation: a review of current techniques and their application in a multi-scale study, central Italy. Geomorphology, 31(1-4), 181-216. DOI: $10.1016 /$ S0169-555X(99)00078-1.

Google Earth (2004). Ortofotosnímka Vysokých Tatier Velká a Malá Studená dolina. Google earth, Image@2014 Eurosense/Geodis Slovakia.

Grass Development Team (2011). Free softvare (GRASS - Geographical Resources Analysis Support System). http:// grass.osgeo.org $>,<$ http://www.grass-gis.org $>$

Gregor, V. (1965). Využitie fotogrametrie pri špeciálnych úlohách vo vysokohorských terénoch. Geodetický a Kartografický Obzor, 11(53), 1, 17-20.

Gregor, V. (2005). Meranie tatranských plies. Geodetický a Kartografický Obzor, 51/93, 1, 9-14.

Gregor. V. \& Pacl J. (2003). Zanášanie tatranských plies. Tatry, 1(42), 12-13.

Gregor, V. \& Pacl J. (2004). Zanášanie tatranských plies II. Tatry, 1(43), 12-13.

Gregor, V. \& Pacl J. (2005). Hydrológia tatranských jazzier. Acta Hydrologica Slovaca, 6(1), 161-187.

Hofmeister, R.J., Miller, D.J., Mills, K.A., Hinkle, J.C. \& Beier A.E. (2002). GIS overview map of potential rapidly moving landslide hazards in western Oregon. IMS22-Text. Oregon: Oregon Department of Geology and Mineral Industries, Portland. https://www.wou.edu/las/physci/taylor/erth350/IMS-22.pdf

Houdek, I. (1943). Tatranské plesá. Zborník Muzeálnej Slovenskej Spoločnosti, 36/37, 246-259.

Hreško, J., Bugár, G., Petrovič, F., Mačutek, J. \& Kanásová D. (2012) Morphodynamic effects on lacustrine deposits in the High Tatras Mts. Ekológia (Bratislava), 31(4), 390-404. DOI: 10.4149/ekol_2012_04_390.

Huggel, C., Kääb, A. \& Haeberli W. (2003). Regional-scale models of debris flows triggered by lake outbursts: the 25 June 2001 debris flow at Täsch (Switzerland) as a test study. In D. Rickenmann \& C. Chen (Eds.), 3rd Int. Conf. on Debris-flow hazards mitigation (pp. 1151-1162). Rotterdam: Millpress.

Hürlimann, M., Copons, R. \& Altimir J. (2006). Detailed debris flow hazard assessment in Andorra: A multidisciplinary approach. Geomorphology, 78(3-4), 359-372. DOI: 10.1016/j.geomorph.2006.02.003.

Iverson, R.M., Schilling, S.P. \& Vallance J.W. (1998). Objective delineation of lahar-inundation hazard zones. Geological Society American Bulletin, 110(8), 972-984. DOI: 10.1130/0016-7606(1998)110<0972:ODOLIH>2.3.CO;2.

Jakob, M. \& Hungr O. (2005). Debris-flow hazards and related phenomena. Berlin: Springer.

Jomelli, V., Pech, V.P., Chochillon, C. \& Brunstein D. (2004). Geomorphic variations of debris flows and recent cli- 
matic change in the French Alps. Clim. Change, 64(1-2), 77-102. DOI: 10.1023/B:CLIM.0000024700.35154.44.

Kapusta, J., Stankoviansky, M. \& Boltižiar M. (2010). Changes in activity and geomorphic effectiveness of debris flows in the High Tatra Mts. within the last six decades (on the example of the Velická dolina and Dolina Zeleného plesa valleys). Studia Geomorphologica Carpatho-Balcanica, 44, 5-34.

Kopecký, M. (2001). Vplyv klimatických a hydrogeologických pomerov na vznik zosuvov. PhD. Thesis, Katedra inžinierskej geológie, Univerzita Komenského v Bratislave.

Kotarba, A. (1992). High energy geomorphologic events in the Polish Tatra Mountains. Geogr. Ann., 74A, 123-131.

Kotarba, A. (2005). Wspólczesne przemiany rzeźby Tatr i innych wysokich gór Europy pod wplywem splywów gruzowych. Przyroda Tatrzańskiego Parku Narodowego a Człowiek, pp. 35-40.

Kotarba, A. (2007). Geomorphic activity of debris flows in the Tatra Mts. and in other European mountains. Geographia Polonica, 80(2), 137-150.

Kotarba, A., Rączkowska, Z., Długosz, M. \& Boltižiar M. (2013). Recent debris flowsin the Tatra Mountains. In D. Loczy (Ed.), Geomorphological impact of extremeweather: Case studies from central and eastern Europe (pp. 221-236). Dordrecht:Springer. DOI: 10.1007/978-94-007-6301-2.

Krcho, J. (1990). Morfometrická analýza a digitálne modely georeliéfu. Bratislava: VEDA, vydavatel’stvo SAV.

Lapin, M., Faško, P., Melo, M., Štastný, P. \& Tomlain J. (2002). Klimatické oblasti. In Atlas krajiny Slovenskej republiky (p. 95). Bratislava: MŽP SR, Banská Štiavnica: Esprit.

Larsen, I.J., Pederson, J.L. \& Schmidt J.C. (2006). Geologic versus wildfire controls on hillslope processes and debris flow initiation in the Green River canyons of Dinosaur National Monument. Geomorphology, 81(1-2), 114-127. DOI: 10.1016/j.geomorph.2006.04.002.

Larsson, S. (1982). Geomorphological effects on the slopes of Longyear Valley, Spitsbergen, after a heavy rainstorm in July 1972. Geografiska Annaler, Series A, Physical Geography, 64( 3-4), 105-125.

Lešková, D. \& Majerčáková O. (2002). Priemerný ročný špecifický odtok. In Atlas krajiny Slovenskej republiky (p. 102). Bratislava: MŽP SR, Banská Štiavnica: Esprit.

Lin, P.-S., Lin, J.-Y., Hung, J.-C. \& Yang M.-D. (2002). Assessing debris-flow hazard in a watershed in Taiwan. Engineering Geology, 66(3-4), 295-313. DOI: 10.1016/S0013-7952(02)00105-9.

Liu, X. \& Lei J. (2003). A method for assessing regional debris flow risk: an application in Zhaotong of Yunnan province (SW China). Geomorphology, 52(3-4), 181-191. DOI: 10.1016/S0169-555X(02)00242-8.

Lukniš, M. (1973). Reliéf Vysokých Tatier a ich predpolia. Bratislava: SAV.

Majerčáková, O. (2002). Povodia hlavných tokov s hydrologickou bilanciou. In Atlas krajiny Slovenskej republiky (p.102). Bratislava: MŽP SR, Banská Štiavnica: Esprit.

Maličký, M. (2012). Fotografie z Prostredného hrotu. Martin Maličký, 10.9.2012.

Malík, P. \& Švasta J. (2002). Hlavné hydrogeologické region. In Atlas krajiny Slovenskej republiky (p. 104). Bratislava: MŽP SR, Banská Štiavnica: Esprit.

Mark, R.K. \& Ellen S.D. (1995). Statistical and simulation models for mapping debris-flow hazard. In A. Carrara \& F. Guzzetti (Eds.), Geographical information systems in assessing natural hazards (pp. 93-106). Dordrecht: Kluwer Academic Publishers.

Melillo, M., Brunetti, M.T., Peruccacci, S., Gariano, S.L. \& Guzetti F. (2016). Rainfall thresholds for the possible landslide occurrence in Sicily (Southern Italy) based on the automatic reconstruction of rainfall events. Landslides, 13(1), 165-172. DOI: 10.1007/s10346-015-0630-1.

Mergili, M., Schratz, K., Ostermann, A. \& Fellin W. (2011). A GRASS GIS implementation of the Savage-Hutter avalanche model and its application to the 1987 Val Pola event. In Proceedings of the Second World Landslide Forum (pp. 1-6).3-7.10.2011, Rome.http://www.mergili.at/publications/mergili_et_al_inpressa.pdf

Nemčok, J. (ed.) (1993). Vysvetlivky ku geologickej mape Tatier 1:50 000. Bratislava: GÚDŠ.

Niedźwiedź, T. (2003). Extreme precipitation events on the northern side of the Tatra Mountains. Geogr. Pol., 76(2), $15-23$.

Pacl, J. (1999). Podiel pozemnej stereofotogrametrie pri mapovaní tatranských plies. In Interdisciplinárne aplikácie $K G S v F$ (pp. 1-5). Bratislava: STU.

Pallas, R., Vilaplana, J.M., Guinau, M., Falgas, E., Alemany, X. \& Munoz A. (2004). A pragmatic approach to debris flow hazard mapping in areas affected by Hurricane Mitch: example from NW Nicaragua. Engineering Geology, 72(1-2), 57-72. DOI: 10.1016/j.enggeo.2003.06.002.

Pasuto, A. \& Soldati M. (2004). An integrated approach for hazard assessment and mitigation of debris flows in the Italian Dolomites. Geomorphology, 61(1-2), 59-70. DOI: 10.1016/j.geomorph.2003.11.006.

Pavlova, I., Jomelli, V., Grancher, D., Brunstein, D. \& Vrac M. (2011). Debris flow occurrence and meteorologi- 
cal factors in the French Alps: A regional investigation. In 5th International Conference on debris-flow hazards mitigation: Mechanics, prediction, and assessment ( pp. 127-134). 14-17, June, 2011, Padua. DOI: 10.4408/ IJEGE.2011-03.B-015.

Pavlova, I., Jomelli, V., Brunstein, D., Grancher, D., Martin, E. \& Déqué M. (2014). Debris flow activity related to recent climate conditions in the French Alps: A regional investigation. Geomorphology, 219, 248-259. DOI: 10.1016/j.geomorph.2014.04.025.

Quantum Gis (QGIS) (2010). Version 1.7.0 - Wroclaw, Built against code revision 63ecdd7. Is licensed under the GNU General Public Licence (www.gnu.org/licenses), free softvere.

Šály, R. (2006). Pôdy alpínskeho a subalpínskeho stupřa Západných Karpát. Zvolen: TU.

Šimo, E. \& Zatko M. (2002). Typy režimu odtoku. In Atlas krajiny Slovenskej republiky (p. 102). Bratislava: MŽP SR, Banská Štiavnica: Esprit.

Šobr, M. \& Česák J. (2006). Methodology and results of bathymetric measurements of the selected High Tatras glacial lakes. Acta Universitatis Carolinae Environmentalica, 20, 109-120.

Štastný, P., Nieplová, E. \& Melo M. (2002a). Priemerná teplota vzduchu v januári. In Atlas krajiny Slovenskej republiky (p. 99). Bratislava: MŽP SR, Banská Štiavnica: Esprit.

Štastný, P., Nieplová, E. \& Melo M. (2002b). Priemerná teplota vzduchu v júli. In Atlas krajiny Slovenskej republiky (p. 99). Bratislava: MŽP SR, Banská Štiavnica: Esprit.

Tomko-Králo, D. (2012). Morfodynamické procesy vysokohorskej krajiny Vysokých Tatier (Malá a Velká Studená dolina). Bakalárska práca, UKF, Nitra.

Tomko-Králo, D. (2014). Súčasný morfodynamický vývoj Velkej a Malej Studenej s dôrazom na zasypávanie a zanášanie plies. Diplomová práca, UKF, Nitra.

Tomlain, J. (2002). Priemerné ročné hodnoty klimatického ukazovatel’a zavlaženia. In Atlas krajiny Slovenskej republiky (p. 95). Bratislava: MŽP SR, Banská Štiavnica: Esprit.

Tomlain, J. \& Hrvol J. (2002). Globálne žiarenie a relatívne trvanie slnečného svitu. In Atlas krajiny Slovenskej republiky (p. 96). Bratislava: MŽP SR, Banská Štiavnica: Esprit.

Vallance, J.W., Cunico, M.L. \& Schilling S.P. (2003). Debris-flow hazards caused by hydrologic events at Mount Rainier. Open-file Report 03-368. Vancouver, Washington: USGS.

Vološčuk, I. a kol. (1994). Tatranský národný park: Biosférická rezervácia. Martin: Gradus.

Zimmermann, M. \& Haeberli W. (1992). Climatic change and debris flow activity in high-mountain areas - a case study in the Swiss Alps. Catena, 22(Suppl.), 59-72. 